\title{
MODELS OF PROJECT TEAMS' FORMATION IN A SAFETY-ORIENTED SYSTEM
}

The subjects of the research are models and methods of optimization and automation of personnel selection in safety-oriented systems with their further formation into project teams on the example of civil protection service, law enforcement agencies of national police, as well as the Armed Forces of Ukraine. Purpose: to develop models for the formation of project teams in safetyoriented systems, taking into account the parameters of personal human qualities and professional skills of candidates for competitive selection based on the global experience of companies in the field of human resources management using software information expert systems. The following tasks are solved in the article: to identify the most effective modern models that can be applied in the civil protection system, taking into account the specifics of the service, on the basis of the use of the European project management toolkit and programs in the field of personnel, organizations, firms and companies. It is necessary to expand the terminological base of management of projects, programs and project portfolios by introducing a new definition of a safety-oriented system. For this research, popular modern automated recruitment systems, as well as expert information systems models, would be considered to capture all relevant information from the database and graphically describe the process of forming project teams in safety systems and to generalize the candidate index model. The following methods are used: human resource management using automated HRM systems, expert information systems and index numbers. The following results were obtained: the model of the structure of the information expert system and the process of knowledge accumulation through the software were developed, an index method for formation of project teams (on the example of military formations) in safety-oriented systems was proposed. Conclusions: a generalized model of expert information system was developed for the selection of personnel into safety-oriented systems based on an index method.

Keywords: safety-oriented system; index method; human resources management; expert systems.

\section{Introduction}

The complexity of forming project teams in Ukraine's security forces is a pressing issue, because the current global trend is the formation of project teams that are endowed with special functions and use a flexible management system that is different from the traditional one, where tasks are placed by a command-administrative method in a vertical structure that causes bureaucracy and corruption situations, through human intervention and incompetence, do not achieve the goals of the organization. European HRM practices use modern project and program management tools to select and further form project teams. They are used in the sphere of public authority, commercial enterprises and organizations. However, in security-oriented systems, these models are not implemented because of the peculiarities of service flow and service.

\section{Analysis of studies and publications}

The questions of studying methods and models of formation of project teams are devoted to the scientific works of such domestic and foreign scientists: Lysenko D.E., Chumachenko I.V., Busheyev S.D., Morozov V.V., Medvid A.P., Danilenko A.I., Sherstyuk O.I., Medvedeva O.M., Rach V.A., Oluyko V.M., Danchenko O.B, Bedrii D.I., Semko I.M., Archibald R., Mazur I.I., Shapiro V.D., Ilyushko V.M., Koshkin K.V. and others.

In his works Lysenko D.E. developed methods and models of selection and choice of the project team as one of the factors of achievement of the set project goals, developed a methodology of functioning of the decision support system (DSS) on the basis of multicriteria evaluation and theory of precedents during which the ranking of "ideal candidate" with further appointment to the position in the project [6]. However, the application of this methodology cannot be applied in the recruitment of civil protection personnel.

A. P. Medvid researched the mechanisms of implementation of personnel policy in the bodies of civil protection as an important lever of development. $\mathrm{He}$ described the development of research methodologies for managerial professional qualities of staff for the analysis of certain groups of civil servants [1]. The use of test results enables the civil servants to be "re-rated" by the integrated indicator, as well as by analyzing certain individual qualities to analyze what needs to be "trained" for staff to be more efficient and in line with professional competence. This work requires the further development of human resource management based on European standards.

Professor I.V. Chumachenko paid special attention to models of formation and management of human resources in the multiproject environment, programs and interaction between project stakeholders [2]. He has developed a competent approach to forming a project team with limited human resources, but this method has a number of limitations that are not suitable for use in a military unit where the scale of human interaction is larger than typical projects.

In his works, the scientist Olenich A.V. studied the peculiarities of forming project teams according to the old and the new approach [10]. He described the issues of staff turnover that form the "bank" of collective experience. He argued that modern success is achieved through the innovation and awareness of all project participants, who are able to achieve their goals quickly and with minimal cost. But paramilitary services do not need to have the entire information base between staff and candidates public, and the implementation of innovative technologies requires effective solutions at low costs, which is not easy to achieve today. 
The Ministry of Internal Affairs specialists developed automated psycho-diagnostic complexes for determining the suitability of candidates for military service and in higher military educational institutions of civil defense [3]. Particular attention in these studies was given to the mental preparedness of candidates under real stressful conditions for the formation of individual characteristics, with subsequent evaluation of applicants for the service. These complexes need refinement and new formalized - described models.

To implement these methods in the civil protection system, it is necessary to take into account the peculiarities of passing and serving. It is necessary to pay attention to the project approach, which is becoming more and more relevant.

\section{Main part}

For military force structures, it is advisable to formulate a new terminology base. We have proposed a new term, namely a security-oriented system.
"Security-oriented system" is a set of organizations, institutions and structures united by a common purpose to ensure the functioning of safe living conditions of the state. These include officers from the military, police, health, security forces of the SES, the Ministry of Internal Affairs, medical personnel and other personnel focused on ensuring the safety and civil protection of the population. For selection in such structures it is advisable to consider the world experience of personnel management.

For the efficiency of human and human resources management, organizations and enterprises use automated information systems, which are referred to as HRM (human resources management system).

These include strategic functions and programs for the workflow of staff records, reporting, planning for the selection of candidates for enterprises, firms and companies through information support for decisionmaking based on competence management, testing, certification, evaluation and other parameters required in the selection of personnel. This area is addressed by HR managers, who use a variety of information systems functionality when interviewing candidates, the functions of HRM systems are shown in fig. 1.

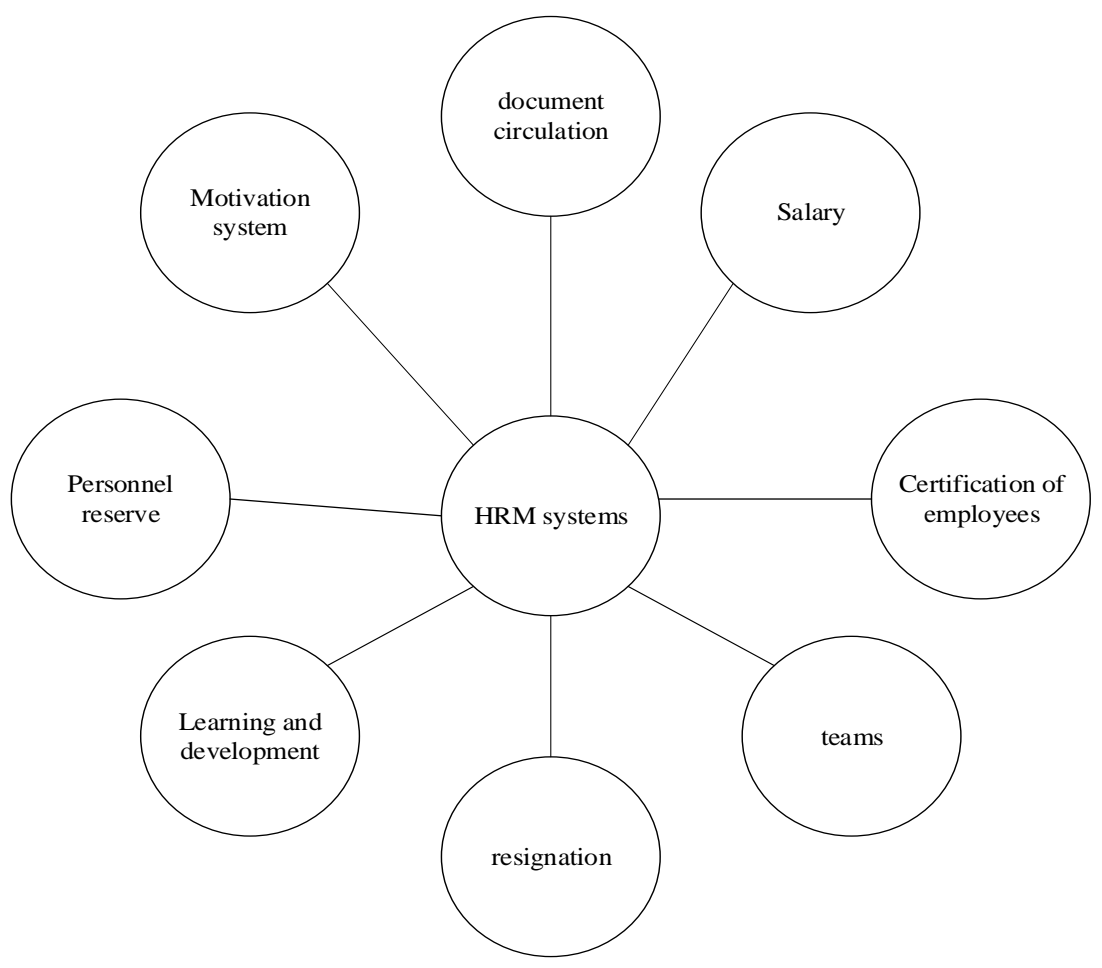

Fig. 1. Object model diagram of HRM systems tasks

Analyzing the global HRM software market, IDC, a leading provider of information and consulting services, was surveyed. According to these data, the leaders in the global HRM systems market are SAP (21\%) - System Analysis and Program Development, Oracle (18\%) and Automatic Data Processing (ADP 14\%), with the remaining companies and firms accounting for only $5 \%$ of the market [15]. The graph of the ratio of the most popular HRM systems is presented in fig. 2.

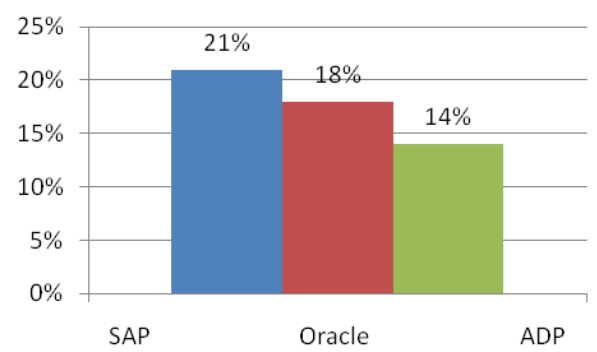

Fig. 2. Graph of percentage of the most popular HRM systems used in the world organizations 
The most developed and popular in terms of implementation are ERP applications that are designed for workforce planning, namely in the western market these are Oracle Application, Axapta and SAPR/3 modules for medium and large businesses, but their software is expensive and implementation methods are complicated for Ukrainian organizations. Analysis of other popular and modern information systems. It is necessary to rely on criteria when choosing the necessary information system, namely: cost, payback system and its functionality.

Among the implemented domestic information HRM systems are the following, which are listed in table 1 [8].

Table 1. List of domestic automated human resource management systems

\begin{tabular}{|c|l|l|l|}
\hline No. & \multicolumn{1}{|c|}{ Name } & \multicolumn{1}{|c|}{ Representation } & \multicolumn{1}{c|}{ Branch } \\
\hline 1 & "Parus-Personnel" & Parus Corporation, representative office in Ukraine & $\begin{array}{l}\text { Software development and } \\
\text { implementation }\end{array}$ \\
\hline 2 & $\begin{array}{l}\text { "1C: Salary and Personnel } \\
\text { Management for Ukraine" }\end{array}$ & $\begin{array}{l}\text { 1C company, representative offices in Ukraine } \\
\text { Trade }\end{array}$ \\
\hline 3 & "Boss-Personnel" & $\begin{array}{l}\text { Ukrainian representative office of the Russian } \\
\text { company "ITi" }\end{array}$ & Information services \\
\hline 4 & "Personnel Active" & Active Consulting Group, Ukraine & Legal services and consulting \\
\hline 5 & "Infopulse HRMS" & Infopulse Ukraine, Ukraine & IT services \\
\hline
\end{tabular}

Modern technologies of functioning of HRM systems and structuring of requirements for candidates will allow to distinguish information system, database of individual psychological characteristics of applicants thanks to the described index method and decision support system (DSS) for successful formation of personnel and fulfillment of their professional and official duties. A model diagram of the formation of a project team in a security-oriented system is presented in fig. 3 .

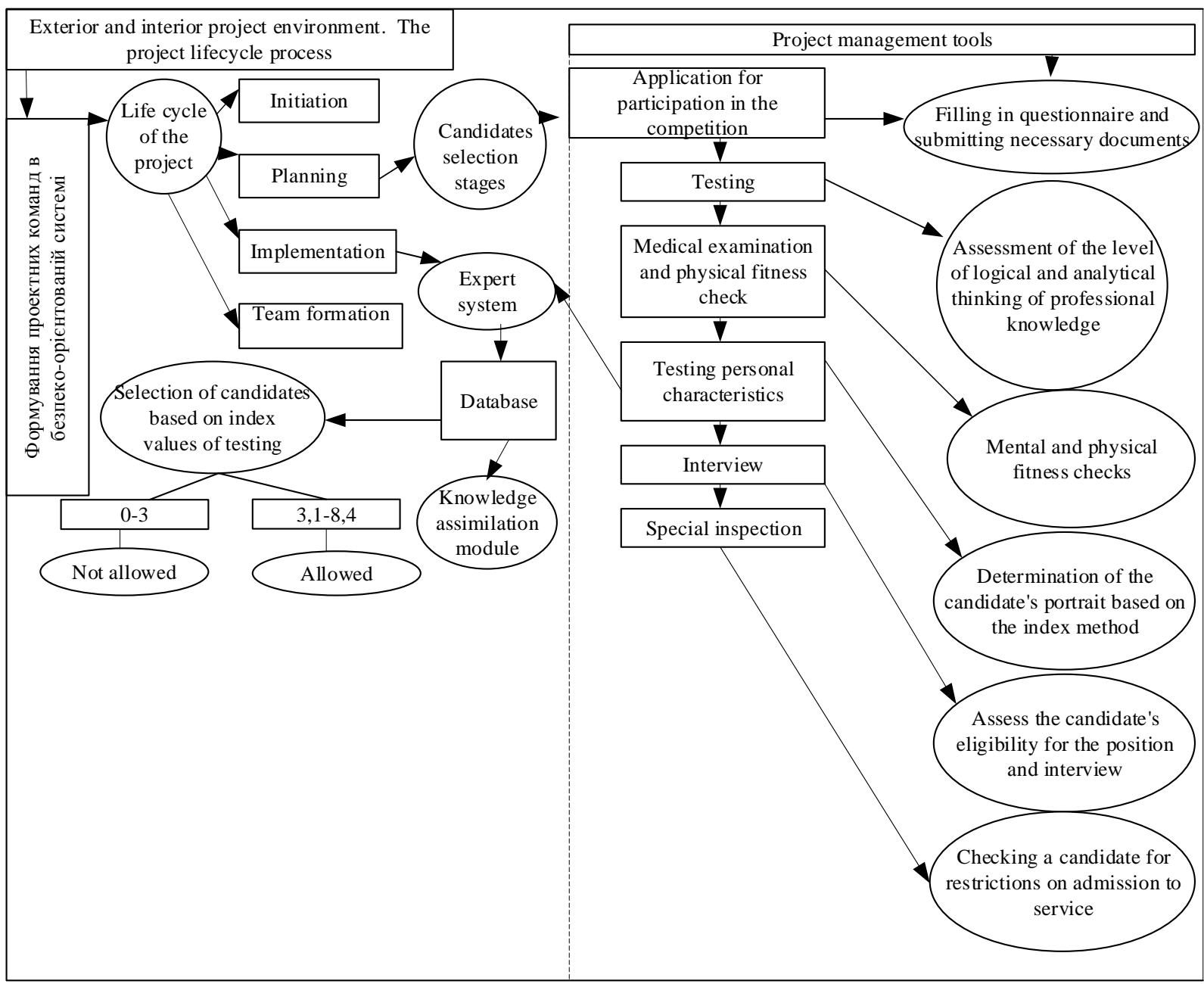

Fig. 3. Model-scheme of formation of the project team in a security-oriented system

In order to optimize and automate the selection process, expert decision support systems for the HR department should be considered.
The Expert System is a computer program that manages knowledge in a specific subject area to solve problems; it is one of the areas of the new field of research 
called Artificial Intelligence (AI), which can replicate the accumulated experience.

The process of knowledge acquisition should include a subject model (in our case a personnel service), an expert system based on an index method, experts (e.g. members of the admissions committee). The process of accumulating experience and knowledge can be seen in fig. 4.

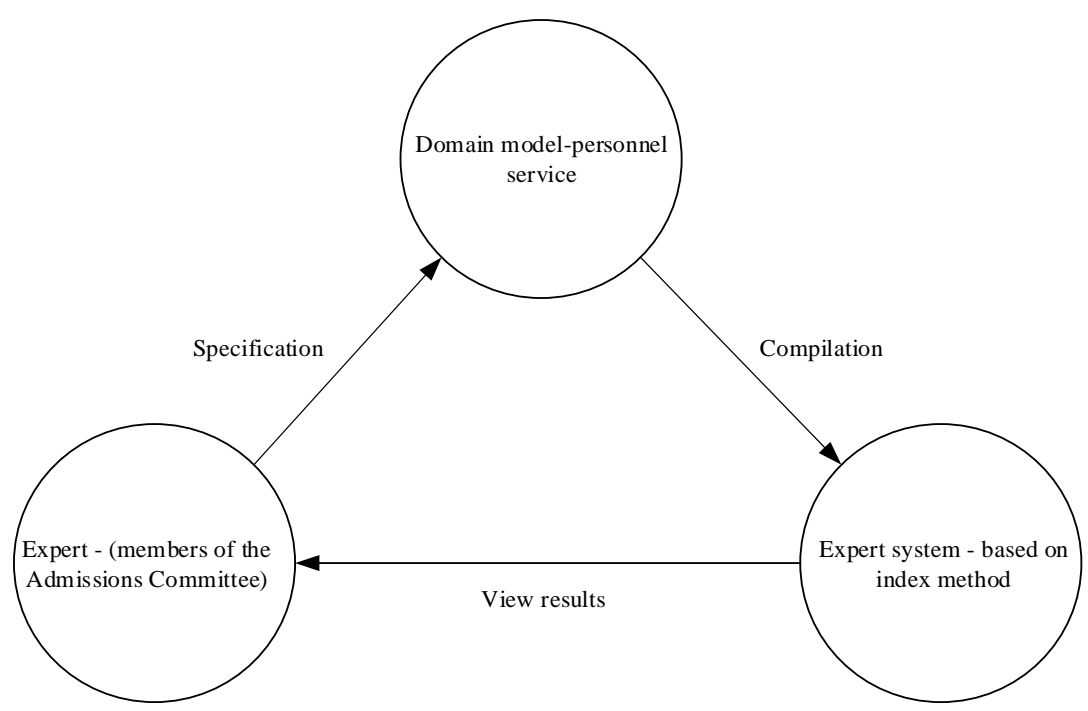

Fig. 4. The process of acquisition (accumulation) of knowledge in the expert system

In our case, it is the selection and formation of the "ideal candidate". The expert system will be able to take on the functions performed by the specialist, thereby minimizing the human factor, eliminating corruption and competently assessing project candidates. It should include a database with the necessary information about the members of the competition - selection, expert (in our case, these may be members of the selection committee), the module of knowledge and knowledge accumulation, which was described in fig. 2, inference system - software with a user-friendly interface for describing the task and providing the processed information. The system is interconnected and an important element is the core of the expert information system.
The expert system includes six logically systematic steps [17]:

1) identification - goal setting, goals, task description, input;

2) conceptualization - analysis and research by subject matter experts is performed;

3) formalization - describes the process of work and the choice of software;

4) implementation - implementation of the project;

5) testing - the competence of the expert system is checked;

6) experimental exploitation of the suitability of the expert system.

The prototype of the expert system is shown in fig. 5 .

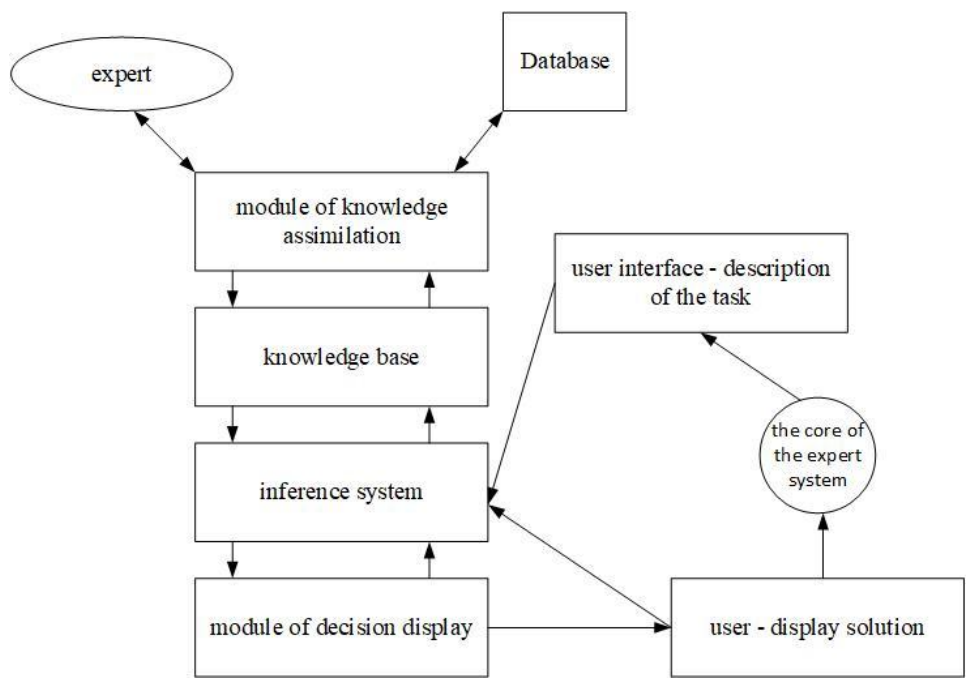

Fig. 5. Prototype of the expert system

In order to develop an expert system, it will be advisable to start by setting general indexes for such military units as the Ukrainian Armed Forces, law enforcement agencies and the civil defense service.
The index method is relative indicators for spatial comparisons, cause and effect, and the identification of the influence of various factors on the subject of study [17]. 
Competencies depending on the type of service in the range [0-1] will affect the overall index indicator, which identifies the necessary personnel depending on the specified parameters. To do this, it is necessary to set the qualitative parameters of numerical values and assign the highest priority for each type of military.
We interviewed HRM systems experts and military personnel, based on which an index estimate of the human qualities lying in the range was proposed $[0 ; 1]$, where 1 is the maximum number allowed (ideal candidate).

Table 2. List of human qualities for selection of candidates on the basis of index method

\begin{tabular}{|l|c|c|c|}
\hline \multicolumn{1}{|c|}{ List of qualities } & Firefighter Rescuer & Police officer & $\begin{array}{c}\text { Soldier of the Armed Forces of } \\
\text { Ukraine }\end{array}$ \\
\hline Motivation & 0.8 & 0.7 & 0.8 \\
\hline Psychological preparation & 0,8 & 0,8 & 0,8 \\
\hline Physical training & 0,8 & 0,8 & 0,8 \\
\hline Technical skill & 0,8 & 0,7 & 0.9 \\
\hline Humanitarian skills & 0,6 & 0,9 & 0,5 \\
\hline Stress resistance & 0,8 & 0,8 & 0,8 \\
\hline Responsibility & 0,8 & 0,9 & 0,9 \\
\hline Confidence & 0,8 & 0,8 & 0,8 \\
\hline Ambitiousness & 0,7 & 0.8 & 0,8 \\
\hline Restraint & 0,8 & 0,8 & 0.5 \\
\hline Ethical standard & 0,7 & 0,8 & 0,5 \\
\hline Total index "of the candidate" & 8,4 & 8,8 & 8,1 \\
\hline
\end{tabular}

The criterion for the selection of personnel was the range of $[0 ; 1]$, which was determined based on the criteria of danger, paperwork and responsibility. The list of human qualities will be considered fundamental parameters, in addition to them there are a number of other criteria that make the security-oriented system difficult to describe and needs to be studied. We have proposed the following numerical limits for decision support, see table 3 .

Table 3. Admission to design teams of security-oriented systems

\begin{tabular}{|l|c|c|c|}
\hline \multicolumn{1}{|c|}{ Profession } & Not allowed & $\begin{array}{c}\text { Admission with subsequent } \\
\text { evaluation }\end{array}$ & Enrollment in the team \\
\hline Firefighter rescuer & $0-3$ & $3,1-6$ & $6,1-8,4$ \\
\hline Police officer & $0-4$ & $4,1-7$ & $7,1-8,8$ \\
\hline Soldier of the Armed Forces of Ukraine & $0-3,5$ & $3.6-5$ & $5,1-8,1$ \\
\hline
\end{tabular}

To improve the selection process, it is necessary to create a staff database before the interview and a questionnaire for each candidate. This database management system will have to contain all the information of the members for the competition-selection, namely: photo, gender, name and surname, education, address and place of residence, general information on administrative - criminal record, medical and mental status as well as the physical ability to serve in military formations.

A generalized example of a candidate's service questionnaire is given in table 4.

Table 4. Questionnaires of the candidate for service

Photo of the candidate

General information
1) full name
2) education
3) place of residence
4) information about no criminal record
5) medical and mental description
6) gender

General information
) education
4) information about no criminal record
6) gender

The candidate's numerical index on the basis of selection and testing will be generated by an information system that is able to optimize the personnel policy process.

\section{Conclusions}

Having analyzed the world experience of using HRM and information expert systems in the process of selection and formation of personnel for project - oriented teams, we have generalized the European model of personnel selection. A new terminological base for "security - oriented systems" has been proposed. They are difficult - described because of the peculiarity of passing and carrying the service. The model scheme of forming the project team in a security-oriented system is developed, the basic necessary criteria for the selection of personnel based on index values in the automated expert systems of human resources management are described, which should positively influence the results of the personnel service of civil protection, law enforcement agencies and military personnel of the Ukrainian military. 


\section{References}

1. Medvid, A. P. (2015), "Personnel policy as an effective lever for the development of the Civil Protection Service of Ukraine in modern conditions" ["Kadrova polityka yak efektyvnyi vazhil rozvytku sluzhby tsyvilnoho zakhystu Ukrainy v suchasnykh umovakh"], Scientific notes of the Institute of Legislation of the Verkhovna Rada of Ukraine, No. 3, P. 122-126.

2. Chumachenko, I. V., Dotsenko, N. V., Sabadosh, L. Yu. (2015), "Methods of forming human resources of multiproject teams and programs" ["Metody formuvannia liudskymy resursamy multyproektnykh komand ta prohram"], Monograph, 202 p.

3. Vorobiova, I. V., Prykhodko, I. I., Poltorak, S. T. (2015), "Selection in the National Guard psychodiagnostic complex" ["Vidbir u natshvardiiu psykhodiahnostychnyi kompleks"], Monograph, P. 18-40.

4. Oluiko, V. M. (2018), "Personnel management under decentralized conditions" ["Upravlinnia personalom v umovakh detsentralizatsii"], Book, P. 176-189.

5. Rossoshanska, O. V., Birukov, O. V. (2010), "Forming a project management team based on a competent approach" ["Formuvannia komandy upravlinnia realizatsiieiu proektu na osnovi kompetentnistnoho pidkhodu"], Project management and production development: a collection of scientific papers, Lugansk : V. Dahl EUNU Publishing House, No. 1 (33), P. $127-146$.

6. Lysenko, D. E. (2009), "Models and methods of forming a project team using precedent theory" ["Modeli ta metody formuvannia komandy proektu z vykorystanniam teorii pretsedentiv"], abstract, Kharkiv, P. 6-15.

7. Danchenko, O. B., Bedrii, D. I., Semko, I. M. (2017), "Identification of personnel risks of scientific projects" ["Identyfikatsiia kadrovykh ryzykiv naukovykh proektiv"], Scientific Periodicals of Ukraine NBUU, P. 19-22.

8. Leli, Yu. H. (2015), "Analysis of existing automated personnel management systems at Ukrainian enterprises" ["Analiz isnuiuchykh avtomatyzovanykh system upravlinnia personalom na ukrainskykh pidpryiemstvakh"], Book, P. 176-189.

9. Hohot, M. M., Chuprina, M. O. "Use of information systems in personnel management" ["Vykorystannia informatsiinykh system v upravlinni personalom"], Topical Problems of Economics and Science: Collection of Scientific Papers of the KPI I. Sikorsky Management Faculty, P. 3-7.

10. Olenich, A. V., Shacka, Z. Ya. (2012), "Formation and development of the project team in modern conditions" ["Formuvannia i rozvytok proektnoi komandy v suchasnykh umovakh"], Topical Problems of Economics, No. 10, P. 3-7.

11. "HRM systems", available at : https://www.simplypersonnel.co.uk/hr-software/info/what-is-a-hr-system/?approve=yes

12. "Information systems HRIS", available at : https://www.thebalancecareers.com/human-resources-information-system-hris1918140

13. Fabrice Delice, Moira Rousseau and Jennifer Feitosa (2019), "Advancing teams research: what, when, and how to measure team dynamics over time", available at : https://www.frontiersin.org/articles/10.3389/fpsyg.2019.01324/full

14. Sandra Morley, Kathryn Cormican, Paul Folan (2015), "An Analysis of Virtual Team Characteristics: A Model for Virtual Project Managers", available at : https://scielo.conicyt.cl/scielo.php?pid=S0718-27242015000100014\&script=sci_arttext\&tlng=en

15. "HRM Systems Research: Market Analysis", (2016), ["Isledovanye HRM system: analiz rynka"], Scientific journal KubSAU, No. 115 (01), available at : https://cyberleninka.ru/article/n/issledovanie-hrm-sistem-analiz-rynka-vybor-i-vnedrenie-dlya-kompaniysrednego-i-krupnogo-biznesa/viewer

16. Okhrimenko, V. M., Voronkova, T. B. (2006), "Information systems and technologies at enterprises" ["Informatsiini systemy i tekhnolohii na pidpryiemstvakh "], Lecture notes (for students and students of FEF and FE specialty "Economics of Enterprise", Kharkiv : KNAMG, 185 p.

17. Rahmat Shazi, Nicole Gillespie, John Steen. (2015), "Trust as a predictor of innovation network ties in project teams", International Journal of Project Management, Vol. 33, Issue 1, P. 81-91.

18. Zachko, O. B., Golovatyi, R. R., Kobylkin, D. S. (2019), "Models of safety management in development projects", Materials of 2019 IEEE 14th International Scientific and Technical Conference on Computer Sciences and Information Technologies (CSIT 2019), Vol. 3, Lviv, P. 81-84.

19. Zachko, O. B., Kobylkin, D. S. (2018), "Discrete-event modeling of the critical parameters of functioning the products of infrastructure projects at the planning stage", Materials of 2018 IEEE 13th International Scientific and Technical Conference on Computer Sciences and Information Technologies (CSIT 2018), Vol. 2, Lviv : Publisher "Vezha i Ko", P. 152-154.

20. Ponomaryov, O. S., Grinchenko, M. A., Lobach, O. V. (2018), "Reliability as a characteristic of the project team", Innovative Technologies and Scientific Solutions for Industries, No. 4 (6), P. 154-160. DOI: https://doi.org/10.30837/2522-9818.2018.6.154

21. Kosenko, V. (2018), "Decision support system in planning investment projects", Innovative Technologies and Scientific Solutions for Industries, No. 4 (6), P. 113-119. DOI: https://doi.org/10.30837/2522-9818.2018.6.113.

Received 28.11.2019

\section{Вiдомості про авторів / Сведения об авторах / About the Authors}

Зачко Олег Богданович - доктор технічних наук, професор, Львівський державний університет безпеки життєдіяльності, професор кафедри права та менеджменту у сфері цивільного захисту, Львів, Україна; email: zachko@ukr.net; ORCID: https://orcid.org/0000-0002-3208-9826.

Зачко Олег Богданович - доктор технических наук, профессор, Львовский государственный университет безопасности жизнедеятельности, профессор кафедры права и менеджмента в сфере гражданской защиты, Львов, Украина.

Zachko Oleh - Doctor of Sciences (Engineering), Professor, Lviv State University of Life Safety, Professor of the Department of Law and Management in the Field of Civil Protection, Lviv, Ukraine.

Кобилкін Дмитро Сергійович - кандидат технічних наук, доцент, Львівський державний університет безпеки життєдіяльності, доцент кафедри пожежної тактики та аварійно-рятувальних робіт, Львів, Україна; етаil: dmytrokobylkin@gmail.com; ORCID: https://orcid.org/0000-0002-2848-3572.

Кобылкин Дмитрий Сергеевич - кандидат технических наук, доцент, Львовский государственный университет безопасности жизнедеятельности, доцент кафедры пожарной тактики и аварийно-спасательных работ, Львов, Украина. 
Kobylkin Dmytro - PhD (Engineering Sciences), Associate Professor, Lviv State University of Life Safety, Associate Professor of the Department of Fire Tactics and Rescue Operations, Lviv, Ukraine.

Ковальчук Олег Ігорович - Львівський державний університет безпеки життєдіяльності, ад’юнкт кафедри права та менеджменту у сфері цивільного захисту, Львів, Україна; email: Justdoitolejka@gmail.com; ORCID: https://orcid.org/00000001-6584-0746.

Ковальчук Олег Игоревич - Львовский государственный университет безопасности жизнедеятельности, адъюнкт кафедры права и менеджмента в сфере гражданской защиты, Львов, Украина.

Kovalchuk Oleh - Lviv State University of Life Safety, Adjunct of the Department of Law and Management in the field of civil protection, Lviv, Ukraine.

\section{МОДЕЛІ ФОРМУВАННЯ ПРОЄКТНИХ КОМАНД В БЕЗПЕКО-ОРІЄНТОВАНІЙ СИСТЕМІ}

Предметом дослідження $є$ моделі та м оптимізації і автоматизації відбору кадрів у безпеко-орієнтованих системах 3 подальшим формуванням їх у проєктні команди на прикладі служби цивільного захисту, правоохоронних органів національної поліції, а також збройних сил України. Мета роботи : розроблення моделей формування проєктних команд у безпеко-орієнтованих системах 3 врахуванням параметрів особистісних людських якостей та професійних навичок кандидатів для конкурсного відбору на основі світового досвіду компаній в сфері управління людськими ресурсами із використанням програмного забезпечення інформаційних експертних систем. В статті вирішуються наступні завдання: на основі використання європейського інструментарію управління проєктами та програмами(видалити слово програм) в сфері найму персоналу в військових формуваннях, організаціях, фірмах та компаніях виокремити найефективніші сучасні моделі, які можна застосувати у системі цивільного захисту з врахуванням специфіки проходження служби. Необхідно розширити термінологічну базу управління проєктами, програмами та портфелями проєктів, шляхом введення нового визначення безпеко-орієнтована система. Для даного дослідження слід розглянути популярні сучасні автоматизовані системи 3 найму персоналу, а також моделі експертних інформаційних систем, які б брали усю необхідну інформацію 3 бази даних та графічно описати процес формування проєктних команд в безпеко-орієнтованих системах та узагальнити модель індексу кандидатів. Використовуються такі методи: управління людськими ресурсами 3 використанням автоматизованих HRM систем, експертні інформаційні системи та індексні числові показники. Отримано наступні результати: розроблено структурну модель інформаційної експертної системи та описано процес накопичення знань завдяки програмному забезпеченню, запропоновано індексний метод формування проєктних команд (на прикладі військових формувань) у безпеко-орієнтованих системах. Висновки: розроблено узагальнену модель-схему експертної інформаційної системи для відбору кадрів у безпеко-орієнтовані системи на основі індексного методу.

Ключові слова: безпеко-орієнтована система; індексний метод; управління людськими ресурсами; експертні системи.

\section{МОДЕЛИ ФОРМИРОВАНИЯ ПРОЕКТНОЙ КОМАНДЫ В БЕЗОПАСНО- ОРИЕНТИРОВАННОЙ СИСТЕМЕ}

Предметом исследования являются модели и методы оптимизации и автоматизации отбора кадров в безопасноориентированных системах с последующим формированием их в проектные команды на примере службы гражданской защиты, правоохранительных органов национальной полиции, а также вооруженных сил Украины. Цель работы: разработка моделей формирования проектных команд в безопасно-ориентированных системах с учетом параметров личностных человеческих качеств и профессиональных навыков кандидатов для конкурсного отбора на основе мирового опыта компаний в области управления человеческими ресурсами с использованием программного обеспечения информационных экспертных систем. В статье решаются следующие задачи: на основе использования европейского инструментария управления проектами и программ в сфере найма персонала в воинских формированиях, организациях, фирмах и компаниях выделить наиболее эффективные современные модели, которые можно применить в системе гражданской защиты с учетом специфики прохождения службы. Необходимо расширить терминологическую базу управления проектами, программами и портфелями проектов, путем введения нового определения - безопасно-ориентированная система. Для данного исследования следует рассмотреть популярные современные автоматизированные системы по найму персонала, а также модели экспертных информационных систем, которые принимали всю необходимую информацию из базы данных и графически описать процесс формирования проектных команд в безопасно - ориентированных системах и обобщить модель индекса кандидатов. Используются такие методы: управление человеческими ресурсами с использованием автоматизированных HRM систем, экспертные информационные системы и индексные числовые показатели. Получены следующие результаты: разработана модель структуры информационной экспертной системы и процесс накопления знаний благодаря программному обеспечению, предложено индексный метод формирования проектных команд (на примере военных формирований) в безопасно-ориентированных системах. Выводы: разработана обобщенная модель экспертной информационной системы для отбора кадров в безопасно-ориентированные системы на основе индексного метода.

Ключевые слова: безопасно-ориентированная система; индексный метод; управления человеческими ресурсами; экспертные системы.

Бібліографічні описи / Bibliographic descriptions

Зачко О. Б., Кобилкін Д. С., Ковальчук О. І. Моделі формування проєктних команд в безпеко-орієнтованій системі. Сучасний стан наукових досліджень та технологій в DOI: https://doi.org/10.30837/2522-9818.2019.10.085.

Zachko, O., Kobylkin, D., Kovalchuk, O. (2019), "Models of project teams' formation in a safety-oriented system", Innovative Technologies and Scientific Solutions for Industries, No. 4 (10), P. 85-91. DOI: https://doi.org/10.30837/2522-9818.2019.10.085. 